\title{
Strategies for regulating tissue fibrosis and their clinical application
}

\author{
Masataka Kuwana
}

Fibrotic conditions account for over 30\% of deaths around the world [1]. Pathologic fibrosis can occur in virtually any organ systems, such as the liver, heart, lungs, kidneys, gastrointestinal tract, bone marrow, and skin. Tissue fibrosis is characterized by excessive accumulation of collagens and other extracellular matrix (ECM) components in parenchymal organs, replacing normal tissue architecture with stiff, acellular fibrous tissue. Fibrotic tissue remodeling is the end result of a cascade of vascular and immune responses to environmental injury and represents a failed tissue repair process, which is self-limited, resulting in scar rather than regeneration [2].

The major producers of ECM are fibroblasts, which are tissue-resident stromal cells of mesenchymal origin. Activated fibroblasts synthesize and secrete ECM macromolecules, growth factors, cytokines, and chemokines, migrate, adhere to, contract, and remodel connective tissue, and transdifferentiate into contractile myofibroblasts [3]. There is increasing recognition that fibroblasts represent a heterogeneous population of cells with diverse origins and functions, even within a single tissue. The ECM-producing cells in the tissue involve not only proliferation of resident fibroblasts, but also transdifferentiation from other tissue resident cell lineages, including pericytes, adipocytes, epithelial cells, endothelial cells, and circulating fibrocytes. ECM also plays a vital role regulating the differentiation, proliferation, migration, adhesion, biosynthetic capacity, and survival of tissue fibroblasts. Moreover, ECM serves as a reservoir for a variety of latent growth factors that regulate tissue fibrosis. Recent findings suggest that mechanical properties of the matrix microenvironment such as matrix rigidity and tension are also responsible for promoting, amplifying, and sustaining the fibrotic process [4]. In a physiologic state, ECM synthesis from fibroblasts is tightly regulated during tissue remodeling, although the impaired control of this

Correspondence: kuwanam@nms.ac.jp

Department of Allergy and Rheumatology, Nippon Medical School Graduate School of Medicine, 1-1-5 Sendagi, Bunkyo-ku, Tokyo 113-8603, Japan regulating system leads to development of pathologic fibrosis. Relevant signals implicated in fibroblast activation in this context include growth factors (i.e., transforming growth factor- $\beta$, platelet-derived growth factor, and connective tissue growth factor), cytokines (i.e., IL-4, IL-6, and IL-13), chemokines (i.e., CCL2, CCL18, CXCL4, and CXCL12), vasoreactive peptides (i.e., endothelin 1 and angiotensin II), bioactive lipids (i.e., prostanoids), reactive oxygen species generated during cellular metabolism, and biochemical and mechanical signals from the surrounding ECM and via direct cell-cell interactions (i.e., Wnt, Notch/ jagged, and Hedgehog signaling) [5]. Finally, chronic inflammation mediated by innate and acquired immune responses also contributes to the tissue fibrosis. A number of molecules, signals, and cell types involved in the process of tissue fibrosis are currently investigated for their potentials for therapeutic targets [6].

This thematic series focuses on updated topics on mechanisms regulating tissue fibrosis and their potential application to novel therapeutic strategies. Since mechanisms underlying pathologic fibrosis are not the same across the organ systems, this series features pathologic fibrosis in the skin, kidney, and heart, which are relevant to human intractable diseases. I hope that these review articles would offer novel insights into tissue fibrosis and contribute to development of novel therapeutic to this devastating condition.

Author's contributions

MK prepared the manuscript and approved the final manuscript.

\section{Competing interests}

The author declares that there are no competing interests.

Published online: 10 April 2020

\section{References}

1. Wynn TA. Common and unique mechanisms regulate fibrosis in various fibroproliferative diseases. J Clin Invest. 2007;117:524-9.

2. Bhattacharyya S, Wei J, Varga J. Understanding fibrosis in systemic sclerosis: shifting paradigms, emerging opportunities. Nat Rev Rheumatol. 2012;8:4254

(c) The Author(s). 2020 Open Access This article is licensed under a Creative Commons Attribution 4.0 International License, which permits use, sharing, adaptation, distribution and reproduction in any medium or format, as long as you give appropriate credit to the original author(s) and the source, provide a link to the Creative Commons licence, and indicate if changes were made. The images or other third party material in this article are included in the article's Creative Commons licence, unless indicated otherwise in a credit line to the material. If material is not included in the article's Creative Commons licence and your intended use is not permitted by statutory regulation or exceeds the permitted use, you will need to obtain permission directly from the copyright holder. To view a copy of this licence, visit http://creativecommons.org/licenses/by/4.0/ 
3. Watsky MA, Weber KT, Sun Y, Postlethwaite A. New insights into the mechanism of fibroblast to myofibroblast transformation and associated pathologies. Intern Rev Cell Mol Biol. 2010;282:165-92.

4. Liu F, Mih JD, Shea BS, et al. Feedback amplification of fibrosis through matrix stiffening and COX-2 suppression. J Cell Biol. 2010;190:693-706.

5. Ho YY, Lagares D, Tager AM, Kapoor M. Fibrosis-a lethal component of systemic sclerosis. Nat Rev Rheumatol. 2014;10:390-402.

6. Varga J, Trojanowska M, Kuwana M. Pathogenesis of systemic sclerosis: recent insights of molecular and cellular mechanisms and therapeutic opportunities. J Scleroderma Relat Disord. 2017;2:137-52.

\section{Publisher's Note}

Springer Nature remains neutral with regard to jurisdictional claims in published maps and institutional affiliations.

Ready to submit your research? Choose BMC and benefit from:

- fast, convenient online submission

- thorough peer review by experienced researchers in your field

- rapid publication on acceptance

- support for research data, including large and complex data types

- gold Open Access which fosters wider collaboration and increased citations

- maximum visibility for your research: over $100 \mathrm{M}$ website views per year

At BMC, research is always in progress.

Learn more biomedcentral.com/submissions 